\title{
COMUNICAÇÃO, MARKETING E RESPONSABILIDADE DA EMPRESA
}

\section{COMMUNICATION, MARKETING AND CORPORATE RESPONSIBILITY}

\begin{abstract}
${ }^{1}$ Frederico de Andrade Gabrich
${ }^{2}$ Maria Fernanda de Souza Sales

\section{RESUMO}

A publicidade, que decorre do planejamento estratégico de marketing da empresa, integra a proposta e o contrato de consumo correspondente ao produto ou serviço ofertado ao mercado. Sendo parte integrante do contrato, a publicidade e as estratégias de comunicação e de marketing da empresa também submetem-se integralmente ao princípio da informação e ao princípio da boa-fé em sua acepção objetiva. Por isso, as estratégias de comunicação, o planejamento de marketing e as ações de propaganda da empresa verdadeiramente cidadã e responsável, devem ser estruturadas juridicamente de forma a considerar todos os deveres conexos à boa-fé.
\end{abstract}

PALAVRAS-ChAVE: Comunicação; Marketing; Publicidade; Princípio da Boa-fé; Princípio da Informação

\begin{abstract}
Advertising, which stems from the strategic planning of the company's marketing, integrates the proposal and the corresponding consumer contract to the product or service offered to the market. As part of the contract, advertising and communication strategies and business marketing also undergo fully the principle of information and the principle of good faith in its objective meaning. Therefore, communication strategies, marketing planning and advertising actions of truly citizen and responsible company should be structured legally in order to consider all related duties in good faith.
\end{abstract}

KEYWORDS: Communication. Marketing; Advertising; Principle of good faith; Principle of Information

\footnotetext{
${ }^{1}$ Doutor, mestre e especialista em Direito Comercial pela Universidade Federal de Minas Gerais - UFMG, Minas Gerais, MG, (Brasil). Professor Adjunto da Fundação Mineira de Educação e Cultura - FUMEC, Minas Gerais, MG, (Brasil). E-mail: frederico.gabrich@gmail.com.

${ }^{2}$ Mestranda em Esfera Pública, Legitimidade e Controle na Fundação Mineira de Educação e Cultura - FUMEC, Minas Gerais, MG, (Brasil). Especialista em Direito Processual pelo Instituto de Educação Continuada - IEC Pontifícia Universidade Católica - PUC Minas Gerais, MG. Bacharel em Direito e Bacharel em Comunicação Social pela da Fundação Mineira de Educação e Cultura - FUMEC, Minas Gerais, MG, (Brasil.) E-mail:
}

Revista Brasileira de Direito Empresarial -le-SSN: 2526-0235| Curitiba | v. 2 | n. 2 | p. 117-134 | Jul/Dez. 2016. 


\section{INTRODUÇÃO}

O contexto globalizante no qual vivemos e os desafios de mercado exigem das empresas uma visão estratégica de negócios.

Nos dias atuais, as organizações empresariais e as organizações públicas dependem do planejamento estratégico para garantia da sobrevivência nos mercados em que atuam. As organizações que não planejam, que não desenvolvem e cumprem os seus planos de ação, que não observam os indicadores de desempenho e que não corrigem periodicamente o próprio planejamento estratégico, acabam sucumbindo ao duro jogo do mercado.

E isso não é diferente em relação às estratégias de comunicação, de marketing e de publicidade, pois essas constituem elementos centrais do desenvolvimento de inúmeros modelos de negócios atuais, centrados fundamentalmente em sistemas subliminares de convencimento voltados para o consumo de bens, de produtos, de serviços.

O Direito quase sempre não é compreendido de forma estratégica pelas empresas e organizações. A maioria dos profissionais do Direito continua acreditando que essa ciência existe fundamentalmente para solucionar conflitos decorrentes da relação entre as pessoas, principalmente por meio do processo judicial.

Acontece que o Direito também precisa ser visto como um dos elementos que devem ser usados pelas empresas para a estruturação de seus planejamentos estratégicos e planos de ação. Mais: o Direito e as normas jurídicas muitas vezes estabelecem limites explícitos para o planejamento e para a atuação empresarial e, em outras situações, esses limites são implícitos e merecem ser descritos pela doutrina, para que possam ser discutidos e aplicados na prática pelas organizações em seus planejamentos e em seus planos de ação. Tudo isso é mais significativo ainda, em um sistema normativo como o brasileiro, estabelecido por diversas fontes do Direito e no qual existem regras e princípios (explícitos e implícitos).

No caso específico das estratégias de comunicação, de marketing e de publicidade, o Direito impõe limites muitas vezes implícitos (e desconhecidos por quem planeja) e decorrentes dos princípios da boa-fé e da informação, independentemente da explicitação de uma regra legal ou contratual específica. E esses limites (explícitos e implícitos) decorrentes da boa-fé são estabelecidos fundamentalmente em nome da cidadania e da responsabilidade social das pessoas e das organizações empresariais (privadas ou públicas). 
É justamente esse o problema que essa pesquisa aborda, por meio do método dedutivo e com amparo no marco teórico estabelecido pelo Código Civil e pela Constituição Federal, quando tratam dos princípios da boa-fé e da informação.

\section{COMUNICAÇÃO, PROPAGANDA E MARKETING}

A comunicação em forma de propaganda, segundo o autor Gilmar Santos (2005, p. 43), tem o objetivo de mudar a atitude das pessoas em relação a uma crença, a uma doutrina ou a uma ideologia. Registre-se que, embora muitas vezes utilize as mesmas ferramentas e se confunda com a publicidade, a propaganda tem objetivos distintos, uma vez que não tem a finalidade de levar as pessoas a praticarem uma ação específica ou imediata, mas busca mudança das atitudes das pessoas em relação a uma idéia. Assim, a propaganda atua na mente e no coração dos indivíduos alvo, predispondo-os favoravelmente em relação ao produto, serviço ou instituição patrocinadora.

A propaganda é "uma caixa de ressonância, uma espécie de tambor que amplifica e aumenta a penetração de tudo o que fazemos" (GRACIOSO, 2002, p. 27). Portanto, segundo Francisco Gracioso (2002, p. 27), a propaganda tem a função de construir, alterar ou até mesmo revigorar pensamentos - o que o autor chama de atitudes mentais - que influenciarão o comportamento humano. A propaganda parte da análise das vantagens para o consumir, que serão divulgadas em um anúncio, e seguir com o aproveitamento da situação favorável que foi criada, com trabalho de vendas e de serviços pós venda, se for o caso.

Nas empresas, "o papel da propaganda deve ser encarado como parte do conjunto de atividades que compõem o marketing, ou seja, o conjunto de atividades que tem por objetivo criar ou estimular a demanda por produtos e serviços, satisfazendo às necessidades e expectativas do consumidor" (GRACIOSO, 2002, p. 20).

Gilmar Santos (2005, p. 43) define a publicidade como "todo processo de planejamento, criação, produção, criação e veiculação de anúncios pagos e assinados por associações específicas (públicas, privadas ou do terceiro setor)” (SANTOS, 2005, p. 44). Nessa perspectiva, as mensagens têm a finalidade de predispor o receptor a praticar uma ação específica.

O autor Gracioso (2002, p. 71), ao falar em comunicação, faz alusão a um fluxo de informação em dois sentidos, do mercado para a empresa, e desta para o mercado, já que a 
empresa deve ouvir o mercado por intermédio da propaganda ou de outras formas de comunicação, por meio de análise estratégica das informações coletadas de diversas formas, como pesquisas, relatórios e diálogos com clientes. Dessa forma, é possível se conhecer as necessidades e expectativas dos clientes, e, consequentemente, preparar-se para atendê-los, com produtos e serviços planejados. Comunicar, então, é uma via de mão dupla em que se envia e recebe informações a todo momento, e é preciso saber fazer uso dessas informações de forma estratégica, especialmente em um ambiente marcado pela competitividade alucinada e baseada no fluxo contínuo e (quase) gratuito de informações.

Nesse sentido, vale transcrever a lição de Gracioso:

\begin{abstract}
A propaganda representa o canal básico de comunicação para o consumidor e exerce também grande influência sobre os canais de distribuição e sobre a própria organização de vendas da empresa. Por fim, os estudos e a pesquisa complementam os canais de comunicação com o mercado, fornecendo ao empresário, informações essenciais sobre os consumidores, o mercado, e os revendedores. Freqüentemente, a informação fornecida pelas técnicas formais de pesquisa revela-se mais complexa e correta do que os informes trazidos pelos vendedores e por outro pessoal do campo da companhia. (GRACIOSO, 2002, p.21).
\end{abstract}

Ao perceber o que interessa ao receptor da mensagem que se pretende transmitir, é possível montar uma boa estratégia de marketing, que consiga ultrapassar a concorrência. Definindo-se vantagens competitivas a serem oferecidas ao alvo, e traçando-se objetivos da própria comunicação com o mercado, é possível se adaptar a forma de comunicação que melhor se apoxima do objetivo que se quer atingir na organização.

Para ilustrar como funciona o gerenciamento de propaganda nas empresas, Shimp expõe:

Gerenciar: Dirigir empresa na condição de gerente; administrar; organizar automaticamente" (Houaiss). Esforços coletivos de inúmeras pessoas são necessários para que uma propaganda seja completa. Neste processo de propaganda estão envolvidos quatro grupos principais: (1) empresas e outras organizações que anunciam - como Protecter e Gamble, McDonald's, o governo dos Estados Unidos, etc.; (2) as agências de propaganda - como Ogilvy and Mather, J. Walter Thompson e Dentsu de Tóquio - que são responsáveis pela criação e veiculação de anúncios para seus clientes; (3) as empresas de produção de propaganda - ou seja, companhias independentes que fotografam, filmam e produzem de qualquer outra forma as propagandas; e (4) os veículos de propaganda - como jornais, televisão, etc. (SHIMP, 2002, p.222).

A estratégia de propaganda, portanto, envolve quatro fatores principais: $O$ estabelecimento de objetivos, a preparação de orçamento, a estratégia das mensagens e a 
estratégia de mídia, que contempla as categorias de mídia e os veículos mais adequados para a transmissão da mensagem. A estratégia se implementra por meio da tática.

A avaliação da eficácia da propaganda é essencial para se perceber, pelos resultados, se os objetivos estão sendo atingidos. Para isso, a pesquisa também é fator de grande importância. "Os objetivos da propaganda são as metas que os esforços de propaganda tentam atingir” (SHIMP, 2002, p. 223). É importante que sejam estabelecidos objetivos antes de serem tomadas decisões em qualquer empresa, e, assim, através de consenso gerencial, é possível definir-se e distribuir-se as tarefas a serem cumpridas. Além disso, os objetivos orientam o orçamento e a estratégia, e fornecem padrões que possibilitam a medição dos resultados.

"Quem, o que, onde, quando e com que freqüência" são as cinco perguntas identificadoras das categorias de objetivos que guiam as estratégias de propaganda. "Quem" diz respeito ao mercado-alvo, suas necessidades básicas e todas as características que influenciam o comportamento de escolha. "O quê" envolve ênfase e metas, ou seja, as características, qualidades e pontos fortes do produto, que devem ser enfatizados, as emoções a serem invocadas, e os objetivos específicos de comunicação ou de vendas que devem ser alcançados na fase atual do ciclo de vida da marca. "Onde", "quando" e "com que freqüência”, estão relacionados com mercados geográficos - ênfase em qual? -, com que meses e estações do ano são os melhores para o anuncio da marca e com que freqüência ela precisa ser anunciada.

Os objetivos diretos procuram uma resposta comportamental do público, uma ação, como a compra de um produto da marca anunciada ou na loja anunciada, por exemplo. É a resposta imediata e explícita a um estímulo de aquisição. Os objetivos indiretos são aqueles voltados para a obtenção de respostas pré-comportamentais, que buscam perceber resultados que antecedem o comportamento, como melhorar ou criar uma imagem positiva de uma marca frente ao público.

Os comunicadores mais inspiradores se preocupam com esse estímulo comportamental para criar algo significativo a partir de produtos cotidianos. Carmine Gallo (2010, p. 11) ilustra essa ideia com exemplos reais: "Howard Schultz, presidente da Starbucks, não vende café. Ele vende um terceiro lugar entre o trabalho e o lar. Suze Orman, guru financeira, não vende fundos fiduciários e mútuos. Ela vende o sonho da liberdade 
financeira". E Steve Jobs, fundador da Apple, não vende computadores, mas "ferramentas para despertar o potencial humano". (GALLO, 2010, p. 11).

Teoricamente, a questão tem o cerne no fato de que, uma vez reconhecido o valor de um produto ou serviço, e o seu impacto positivo na vida de uma pessoa, o objetivo de conquista terá sido atingido.

Por isso, o marketing é um sistema que serve para criar valor para o cliente, e funciona combinando variáveis controláveis - como produto, preço, praça e promoção - e incontroláveis - como economia, política e demografia. Assim, o marketing é um conjunto de elementos interdependentes, que funcionam como uma engrenagem, possibitando a ação estratégica.

O marketing trabalha identificando as necessidades, que são as carências e privações humanas básicas, utilitárias, hedônicas, psicológicas, fisiológicas, sociais, de segurança e auto realização. A partir dessa identificação, busca satisfazer tais necessidades por meio do estímulo aos desejos - anseios por satisfações específicas aprendidas - e consequente criação de demandas - aspirações por produtos específicos.

A criação de valor e sua percepção, se dão por meio da relação entre atributos, que são os benefícios, e preço, uma vez que o valor de determinado produto é agregado quando se percebe a vantagem que se tem com ele.

Para Phillip Kotler, marketing "é um processo social por meio do qual pessoas e grupos de pessoas obtêm aquilo de que necessitam e o que desejam com a criação, oferta e livre negociação de produtos e serviços de valor com os outros", e administração de marketing "é o processo de planejar e executar a concepção, a determinação do preço, a promoção e a distribuição de idéias, bens e serviços para criar negociações que satisfaçam metas individuais e organizacionais" (KOTLER, 2001, p. 79).

A questão, entretanto, é demonstrar que tanto a publicidade, quanto o marketing encontram limites em uma visão estratégica e estruturante do Direito, para determinar a cidadania e a responsabilidade da empresa.

\section{DIREITO: PLANEJAMENTO E ESTRATÉGIA}

A delimitação de objetivos deve ser a base para a tomada de todas as decisões das pessoas. Em âmbito pessoal e profissional, delimitar objetivos e estratégias do que se fazer 
para atingir pretensões é caminho único e essencial para o sucesso. Entes da Administração Pública, pessoas físicas ou jurídicas, de Direito Público ou Privado, todos devem gerenciar-se por meio do delineamento de objetivos e estratégias para que sejam eles atingidos.

Gabrich (2010) ensina que planejar é construir cenários possíveis, com objetivo de antever ou antecipar o futuro, para a concretização dos objetivos previamente estabelecidos. E prossegue, definindo, que, nesse sentido, o planejamento implica a elaboração de um conjunto de ações voltadas para implementação dos objetivos pré-determinados. Além disso, o mesmo autor afirma que a estratégia é a arte de aplicar recursos, visando alcançar os objetivos definidos, com a máxima eficácia possível.

Para Gabrich (2010), existem diversas normas e alternativas jurídicas colocadas no ordenamento e que estão à disposição para a concretização e para a eficácia dos objetivos traçados pelo estrategista. Mas essas mesmas normas e alternativas que abrem possibilidades de planejamento e ação, muitas vezes impõe limites e restrições não escritas.

Nesse sentido, o princípio que antes era da legalidade estrita e segundo o qual ninguém seria obrigado a fazer ou deixar de fazer alguma coisa senão em virtude de uma lei, passa a ser compreendido como princípio da normatividade, segundo o qual ninguém será obrigado a fazer ou deixar de fazer alguma coisa senão em virtude de norma jurídica (estabelecida pela lei, pela jurisprudência, pelo contrato, pelos atos administrativos) existente, válida e eficaz. E esses novos padrões de hermenêutica devem ser considerados para análise da possibilidade de eventual implemento de qualquer estratégia empresarial.

Por isso:

Para realizar a análise estratégica do Direito e propor alternativas jurídicas para a realização eficaz dos objetivos traçados, o jurista deve não apenas conhecer a pessoa, empresa ou negócio, mas também as normas jurídicas existentes, válidas e eficazes no ordenamento, bem como a doutrina e a jurisprudência relativas a essas normas. Além disso, o jurista deve ter conhecimentos básicos de outras ciências (Economia, Administração, Contabilidade, Psicologia, dentre outras), deve ter capacidade de trabalhar em equipe e deve, necessariamente, ser ativo, reflexivo e criativo. [...] O jurista contemporâneo deve ser criativo para realizar a análise estratégica do Direito e para apresentar alternativas jurídicas viáveis para a concretização dos objetivos propostos. O estrategista jurídico não pode apenas e sempre repetir as soluções do passado, pois normalmente elas foram estabelecidas a partir de outras circunstâncias de fato e de direito, e, por isso, nem sempre preenchem as condições necessárias para a regulação eficaz de outra ou da mesma situação, em outro momento. Todavia, o grande problema é que o ensino jurídico (na graduação e na pósgraduação) não está preparado para essa nova realidade. (GABRICH, 2010).

Revista Brasileira de Direito Empresarial -le-SSN: 2526-0235| Curitiba | v. 2 | n. 2 | p. 117-134 | Jul/Dez. 2016. 
De fato, a deficiência na formação dos juristas com essa visão estratégica do Direito, tem inúmeros reflexos práticos na atuação empresarial, pois o sistema normativo não é considerado pelos advogados e pelos estrategistas das organizações em toda a sua dimensão no momento de elaboração de uma estratégia empresarial, o que também acontece em relação ao marketing e à publicidade.

\section{O PRINCÍPIO DA INFORMAÇÃO}

A Constituição da República Federativa do Brasil, de 5 de outubro de 1988, muito mais que um sistema de normas fundamentais positivadas, é, sem nenhuma dúvida, uma Constituição cuja dimensão principiológica é marcante e fundamental na determinação da lógica de funcionamento do atual ordenamento jurídico nacional.

E foi justamente a partir da Constituição da República de 1988 que os princípios passaram a ser unissonamente considerados, no Brasil, pela doutrina e, sobretudo, pela jurisprudência, como normas jurídicas de caráter obrigatório, impositivo e determinadoras de “dever-ser”, além dos já então propalados e reconhecidos sentidos programático e interpretativo dos princípios jurídicos.

Nesse sentido, segundo Cármen Lúcia Antunes Rocha (1994. p. 23), os princípios constitucionais são conteúdos intelectivos dos valores superiores adotados pela sociedade política e formam a essência do sistema constitucional. Os princípios constitucionais, dotados de originalidade, superioridade material, normatividade jurídica e eficácia plena, são os conteúdos primários e diretores de todo o sistema jurídico normativo fundamental do Estado. Por isso, segundo a mesma autora, a ordem constitucional brasileira forma-se, informa-se e conforma-se pelos princípios por ela adotados.

Apesar de os princípios constitucionais terem normatividade e caráter impositivo incontestável, as normas principiológicas (constitucionais ou infraconstitucionais) muitas vezes não são fixadas por meio de uma definição precisa, imutável, ou com significado unívoco. Os princípios são polissêmicos e polivalentes. E são justamente essas características que permitem a abertura e a renovação permanente do sistema. São os princípios, portanto, que possuem a capacidade de manter a dimensão sistêmica da ordem constitucional brasileira, dando-lhe fecundidade e permitindo a sua atualização permanente, adequando-se ao sentido 
daquilo que a maioria do povo acolhe como justo em cada momento histórico (ROCHA, 1994. p. 23-26).

De qualquer maneira, é fundamental ressaltar que os princípios constitucionais são predeterminantes e ordenadores do regramento jurídico. Por isso, não é possível a prevalência de regra ou princípio, de lei ou de contrato, de costume ou de jurisprudência, ou de planejamento ou atuação empresarial, que não se conforme e se adapte aos comandos generalíssimos estabelecidos pelos princípios explícitos ou implícitos da Constituição.

Nesse contexto, a Constituição brasileira, em seu Título II, Capítulo I, artigo $5^{\circ}$, estabelece uma série de direitos e de garantias fundamentais, de caráter individual e coletivo, basicamente destinadas a assegurar a inviolabilidade da vida, da liberdade, da igualdade, da propriedade e da segurança, garantindo a imposição desses valores, em qualquer hipótese, a quaisquer pessoas, brasileiras ou estrangeiras, que entrem em contato ou estejam sujeitas à ordem jurídica brasileira.

De fato o princípio da informação é estabelecido na Constituição da República Federativa do Brasil, em seu artigo $5^{\circ}$, entre os direitos e garantias fundamentais e individuais, em dois incisos.

Assim, segundo o disposto no inciso XIV, do artigo $5^{\circ}$, da Constituição brasileira:

XIV - é assegurado a todos o acesso à informação e resguardado o sigilo da fonte, quando necessário ao exercício profissional.

Trata-se, sem qualquer dúvida, da norma constitucional que impõe a existência jurídica plena do princípio da informação, com todas as suas características fundamentais, posto que é dotado de originalidade, superioridade material, normatividade jurídica e eficácia plena, estabelecendo conteúdo primário e diretor de todo o sistema jurídico normativo.

Segundo Celso Ribeiro Bastos (1989, p. 81), o dispositivo mencionado não determina o direito aos meios de informar, mas consagra o chamado direito de se informar, que consiste na liberdade de busca da informação, de procura de fontes de informação, no direito que a pessoa tem de não ser impedida de ser informada.

Já o direito que a pessoa tem de ser mantida adequada e verdadeiramente informada é determinado pelo inciso XXXIII, do mesmo artigo, que, complementando o conteúdo do princípio da informação, assim estabelece: 
XXXIII - todos têm direito a receber dos órgãos públicos informações de interesse particular, ou de interesse coletivo ou geral, que serão prestadas no prazo da lei, sob pena de responsabilidade, ressalvadas aquelas cujo sigilo seja imprescindível à segurança da sociedade e do Estado.

Fica evidente, então, não somente o direito que as pessoas possuem de externar livremente suas ideias e pensamentos (princípio da liberdade de expressão, do qual decorre o princípio da informação), mas, também, a liberdade de prestar e recolher (exigir) informações. O legislador constituinte deixou claro que não se pode mais admitir qualquer tipo de comportamento individualista ou egoísta, que leve à utilização de quaisquer técnicas sofisticadas e/ou agressivas de informação, informações não verdadeiras, ou mesmo a ausência delas, visando a debilitar ou até destruir a livre formação da vontade (GUIMARÃES, 2001, p. 290-291).

Não obstante, os mesmos dispositivos constitucionais que impõem a existência plena do princípio da informação, em âmbito público e privado, vislumbram e determinam a existência de limites e de controles, estabelecidos em nome de interesses econômicos, culturais, políticos e sociais de toda a comunidade.

\section{A BOA-FÉ OBJETIVA}

Segundo o disposto no artigo 113 do Código Civil brasileiro, os negócios jurídicos devem ser interpretados conforme a boa-fé e os usos do lugar de sua celebração. Como se não bastasse, de acordo com o artigo 422 do Código Civil, os contratantes são obrigados a guardar, assim na conclusão do contrato, como em sua execução, os princípios de probidade e boa-fé.

Desses dispositivos legais, principalmente, surge a boa-fé em sua acepção objetiva no ordenamento jurídico brasileiro. E a expressão objetiva da boa-fé, não se reportando propriamente a estados de consciência ou de ignorância internos relativos ao sujeito, surge como regra de conduta previamente estabelecida e definida como bitola de um comportamento ético e moral nas relações tratadas pelo Direito.

Dessa maneira, o aspecto subjetivo da boa-fé (ignorância do sujeito relativamente ao ilícito) traduz-se, objetivamente, na realidade afeta às regras de conduta, formalizando-se e concretizando-se, normalmente, nos chamados “deveres anexos aos negócios jurídicos”, entre os quais se destacam: a lealdade, o cuidado, a diligência, a transparência e a informação. 
Enquanto a boa-fé subjetiva está relacionada ao estado de consciência ou de convencimento do agente em atuar em conformidade com o direito, a boa-fé objetiva constitui um modelo de conduta social (que, em tese, deveria ser inerente às pessoas), de acordo com o qual cada pessoa deve agir com honestidade, lealdade e probidade, considerando-se sempre os fatores econômicos, sociais, políticos, etc. envolvidos no caso concreto (MARTINS-COSTA, 1999, p. 411). A boa-fé objetiva surge, então, como algo exterior ao sujeito, mas que a lei geralmente não define de modo concreto, de maneira a permitir a subsunção direta do fato à norma.

De qualquer maneira, a doutrina geralmente reconhece que a boa-fé objetiva possui três funções distintas, podendo se nos apresentar como: (1) cânone hermenêutico integrativo do contrato; (2) norma de criação de deveres jurídicos instrumentais; e (3) norma de limitação ao exercício de direitos subjetivos (AGUIAR JÚNIOR, 1995, p. 23; MARTINS-COSTA, 1999, p. 427-428).

A primeira função reconhecida à boa-fé objetiva faz dela elemento hermenêutico fundamental ao preenchimento de lacunas em matéria contratual, alargando o conteúdo jurídico dos contratos e alcançando todos os momentos e fases do negócio jurídico, desde antes da celebração do contrato, até depois do cumprimento das obrigações (culpa post pactum finitum). ${ }^{3}$ Assim, em sua acepção objetiva, a boa-fé manifesta-se como máxima objetiva do Direito das obrigações, que determina deveres não previstos, obrigatoriamente, no negócio, e endereçados a todos os contratantes, inclusive os credores, que, tradicionalmente, sempre foram considerados como titulares de direitos e não necessariamente de deveres ou de obrigações (COUTO E SILVA, 1976, p. 29).

Assim, a boa-fé tem função integradora da obrigação, pois atua, ao lado do contrato e da vontade das partes, como fonte de direitos e de obrigações. Além disso, nesse primeiro sentido, a boa-fé objetiva constitui fator fundamental na interpretação das cláusulas do contrato, de maneira a permitir, na prática, a imposição da lealdade das partes, da moralidade

\footnotetext{
${ }^{3}$ Segundo Menezes Cordeiro (1997, p. 625-631), a culpa post pactum finitum corresponde à projeção simétrica da culpa in contrahendo no período pós-contratual", que determina a manutenção de deveres de proteção, informação e lealdade para os ex-contratantes, mesmo após o cumprimento das obrigações principais do negócio jurídico. É o caso, por exemplo, dos deveres de informação e de proteção da fábrica de automóveis, que, mesmo após a conclusão do negócio, fica obrigada a prestar informações acerca do funcionamento anormal de peças e componentes, bem como de promover a substituição das mesmas (recall), além de garantir a manutenção da assistência técnica e o fornecimento de peças.
} 
da pretensão do credor e da correção da resistência do devedor (AGUIAR JÚNIOR, 1995, p. 25).

Portanto, no caso específico dos contratos (especialmente os empresariais e de consumo), a utilização e a aplicação do princípio da boa-fé, em sua concepção objetiva, mostra-se fundamental, pois permite que se exija continuamente dos contratantes - desde o momento em que a estratégia de comunicação, marketing e propaganda é estabelecida e que antecede à formalização de qualquer negócio, chamado de pré-contratual, até o momento posterior ao da rescisão - o cumprimento dos seus deveres de informação, de diligência e de lealdade recíprocas, que exprimem um comportamento ético, moral e de boa-fé absolutamente fundamental para o desenvolvimento jurídico-mercantil, em bases sólidas e marcadas pela fidúcia.

A segunda função reconhecida pela doutrina à boa-fé objetiva atribui a ela a responsabilidade pela criação e pela imposição de deveres jurídicos conexos ou instrumentais, tais como: o direito (dever) de informação, o dever de cooperação recíproca, o dever de cuidado e de proteção do patrimônio e/ou da pessoa da contraparte, o dever de omissão e de segredo, dentre outros. Todos esses deveres devem ser imputados à boa-fé objetiva e não, necessariamente, às cláusulas expressas do contrato.

Alguns desses deveres acessórios podem ser classificados como deveres de proteção e determinam que as partes de um contrato têm o dever mútuo de evitar que sejam causados prejuízos ao patrimônio da contraparte, durante todo o fenômeno ou procedimento contratual (tratativas, celebração, execução, rescisão, pós-execução).

Outros desses deveres instrumentais são chamados deveres de esclarecimento e obrigam as partes, desde a fase pré-contratual das primeiras negociações, até depois da execução do contrato, a informarem-se mutuamente a respeito de tudo aquilo que possa influir, direta ou indiretamente, no vínculo. ${ }^{4}$

Finalmente, existem os chamados deveres acessórios de lealdade, segundo os quais, na pendência do contrato, as partes devem abster-se de todos os comportamentos que possam falsear o objetivo do negócio, ou determinar desequilíbrio das prestações. Entre esses comportamentos ou obrigações impostas às partes pela boa-fé objetiva e decorrentes do dever

\footnotetext{
${ }^{4}$ Nesse contexto insere-se a teoria da culpa in contrahendo. Basicamente, segundo essa teoria, os contratos nulos também determinam responsabilidade civil dos contratantes, relativamente às despesas e aos custos da preparação e da celebração do negócio jurídico. Além disso, em virtude da culpa in contrahendo, a assunção voluntária de negociações contratuais é fonte de deveres, de obrigações e de responsabilidade pré-contratual, entre os quais se destacam: os deveres de proteção, de esclarecimento, de lealdade e de informação.
} 
de lealdade, destacam-se: a não-concorrência; o dever de não celebrar negócios posteriores incompatíveis com o primeiro contrato; o sigilo relativo às informações obtidas em virtude do contrato (tal como o know how). (CORDEIRO, 1997, p. 604-607).

Finalmente, a terceira função normalmente estabelecida para a boa-fé objetiva é a de atuar como limitadora ao exercício de direitos subjetivos. Nesse caso, a boa-fé objetiva atua para não admitir o exercício de direitos que contrariem os seus comandos genéricos de respeito à finalidade (econômica e social) do ato, ou que não permitam a imposição de uma atitude leal, proba e honesta do artífice do negócio jurídico.

Conforme o disposto no artigo 427 do Código Civil brasileiro:

Art. 427. A proposta de contrato obriga o proponente, se o contrário não resultar dos termos dela, da natureza do negócio, ou das circunstâncias do caso.

Além disso, de acordo com o artigo 429 do Código Civil:

Art. 429. A oferta ao público equivale a proposta quando encerra os requisitos essenciais ao contrato, salvo se o contrário resultar das circunstâncias ou dos usos.

No mesmo sentido, segundo o artigo 30 do Código de Defesa do Consumidor:

Art. 30. Toda informação ou publicidade, suficientemente precisa, veiculada por qualquer forma ou meio de comunicação com relação a produtos e serviços oferecidos ou apresentados, obriga o fornecedor que a fizer veicular ou dela se utilizar e integra o contrato que vier a ser celebrado.

Por conta desses dispositivos legais, em muitos casos, a publicidade (que é consequência dos planejamentos estratégicos de comunicação e de marketing de uma organização), quando oferece ao consumidor uma determinada ideia, um determinado produto ou serviço, faz isso como parte integrante de um contrato, especialmente no caso das relações de consumo.

Nesse sentido, destacam-se as seguintes ementas:

AÇÃO DE RESCISÃO CONTRATUAL C.C. INDENIZAÇÃO POR DANOS MORAIS - CONTRATO DE EMPRÉSTIMO CONSIGNADO - Oferta de quitação

Revista Brasileira de Direito Empresarial -le-SSN: 2526-0235| Curitiba | v. 2 | n. 2 | p. 117-134 | Jul/Dez. 2016. 
de dívida (existente perante outra Instituição Financeira) e pactuação de novo contrato em condições mais vantajosas - Instrumento contratual assinado em branco e preenchido de forma diversa da ofertada - Descabimento - Vinculação do proponente aos termos da proposta realizada - Arts. 427 e 429, do Código Civil, e 30 e 35, do Código de Defesa do Consumidor - Resolução do contrato determinada corretamente - Necessidade de restituição das partes ao estado anterior [...] (SÃO PAULO, 2015).

APELAÇÃO CÍVEL. CONTRATO DE CARTÃO DE CRÉDITO. AÇÃO INDENIZATÓRIA POR DANOS MORAIS. DANO MORAL CONFIGURADO. Recusa de cumprimento de oferta. Emitida oferta pública com dados objetivos, a recusa ou negativa de contratar por parte do proponente ou policitante deve ser justificada, isto é, amparada em elemento objetivo que pese contra o consumidor, ou, no mínimo, em um motivo razoável para negar o contrato. Exegese do disposto nos arts. 427 e 429 do Código Civil, combinado com os arts. 30, e 35, inc. III (parte final), do Código de Defesa do Consumidor. [...] (RIO GRANDE DO SUL, 2011).

Não obstante, segundo o artigo 36 do Código de Defesa do Consumidor:

Art. 36. A publicidade deve ser veiculada de tal forma que o consumidor, fácil e imediatamente, a identifique como tal.

Parágrafo único. O fornecedor, na publicidade de seus produtos ou serviços, manterá, em seu poder, para informação dos legítimos interessados, os dados fáticos, técnicos e científicos que dão sustentação à mensagem.

Dessa maneira, do ponto de vista jurídico estratégico, os planejamentos de comunicação e de marketing, que antecedem à publicidade, também deve ser desenvolvidos de maneira a respeitarem não apenas o princípio da informação, segundo o qual a comunicação e o marketing devem exprimir todas as verdadeiras características dos produtos e/ou serviços ofertados ao mercado, como, também, o princípio da boa-fé em sua acepção objetiva, com a total garantia de eficácia dos deveres de proteção, de cuidado, de esclarecimento e de lealdade que lhe são inerentes.

De fato, os princípios da informação e da boa-fé, considerados plenamente e em conjunto, impõem aos fornecedores muito mais do que a manutenção de dados fáticos, técnicos ou científicos que dão sustentação à mensagem publicitária, para eventual consulta dos legítimos interessados (como previsto no parágrafo único, do artigo 36 do Código do Consumidor), mas a efetiva revelação da estratégia subliminar imaginada e desenvolvida por meio dos planos de comunicação, de marketing e de publicidade.

Daí o motivo pelo qual, no plano jurídico estratégico e teórico, a publicidade deve ser realizada de tal forma que os consumidores tenham condições de conhecer, mesmo que por meio de um documento à parte, os verdadeiros objetivos subliminares estrategicamente 
pensados durante o desenvolvimento dos planos de comunicação e de marketing da organização, sob pena de violação tanto do princípio da informação, quanto do princípio da boa-fé objetiva.

Não obstante, segundo o disposto no parágrafo único, do artigo 116 da Lei n. 6.404/76, que trata das sociedades por ações, e que acaba sendo utilizada supletiva ou analogicamente para a organização da maioria das sociedades empresárias brasileiras:

Parágrafo único. O acionista controlador deve usar o poder com o fim de fazer a companhia realizar o seu objeto e cumprir sua função social, e tem deveres e responsabilidades para com os demais acionistas da empresa, os que nela trabalham e para com a comunidade em que atua, cujos direitos e interesses deve lealmente respeitar e atender.

Como se não fosse suficiente, o artigo 154 da mesma Lei n. 6.404/76, estabelece o seguinte:

Art. 154. O administrador deve exercer as atribuições que a lei e o estatuto lhe conferem para lograr os fins e no interesse da companhia, satisfeitas as exigências do bem público e da função social da empresa.

Desses dispositivos, sem nenhuma dúvida, decorrem a cidadania e a função social que as empresas devem observar em todos os seus atos de planejamento e de ação, entre os quais destacam-se os planos de comunicação, de marketing e a publicidade deles decorrente, que precisa sempre respeitar não apenas o princípio da informação, mas também todos os deveres conexos inerentes à boa-fé objetiva.

\section{CONCLUSÕES}

A empresa responsável e cidadã é aquela que assume e cumpre responsabilidades estabelecidas por todas as normas jurídicas (princípios e regras) definidas no ordenamento, mas que também se preocupa com a sua perenidade sustentável, o que somente é possível por meio do desenvolvimento e da implantação de um (ou de vários) planejamento(s) estratégico(s). E de acordo com essa lógica, a comunicação e o marketing são fatores críticos de sucesso para diversos modelos de negócios atuais.

A comunicação em forma de propaganda tem o objetivo de mudar a atitude das pessoas em relação a uma crença, a uma doutrina ou a uma ideologia. O marketing, todavia, é 
um sistema que serve para criar valor para o cliente, e funciona combinando variáveis controláveis, tais como produto, preço, praça e promoção, e incontroláveis, como economia, política e demografia, possibilitando a competição.

O marketing propõe a identificação das necessidades das pessoas, que são as carências e privações humanas básicas, e busca, através disso, satisfazê-las por meio do estímulo aos desejos e consequente criação de demandas. No marketing, a criação de valor se dá principalmente por meio da relação entre atributos, benefícios e preço, visto que é partindo da percepção da vantagem que determinado produto ou serviço proporciona é que será agregado valor a ele.

Em virtude do disposto nos artigos 427 e 429 do Código Civil, e do artigo 30 do Código do Consumidor, a publicidade, que decorre do planejamento estratégico de marketing da empresa, integra a proposta e o contrato de consumo correspondente ao produto ou serviço ofertado ao mercado. Sendo parte integrante do contrato, a publicidade e as estratégias de comunicação e de marketing da empresa também submetem-se integralmente ao princípio da informação (artigo $5^{\circ}$, incisos XIV e XXXIII da Constituição) e ao princípio da boa-fé em sua acepção objetiva, especialmente em virtude do disposto nos artigos 113 e 422 do Código Civil.

Assim sendo, as estratégias de comunicação, o planejamento de marketing e as ações de propaganda da empresa verdadeiramente cidadã e responsável, devem ser estruturadas juridicamente de forma a considerar todos os deveres conexos à boa-fé, independentemente de norma explícita e direta, e devem ser realizadas de tal forma que os consumidores tenham condições de conhecer, mesmo que por meio de um documento à parte, os verdadeiros objetivos subliminares estrategicamente pensados durante o desenvolvimento desses planos de comunicação e de marketing da organização

\section{REFERÊNCIAS}

AGUIAR JÚNIOR, Ruy Rosado. A boa-fé na relação de consumo. Revista de Direito do Consumidor, São Paulo, vol. 14, abr.-jun. de 1995.

BASTOS, Celso Ribeiro, MARTINS, Ives Gandra. Comentários à Constituição do Brasil: promulgada em 5 de outubro de 1988. São Paulo: Saraiva, 1988-1989.

BRASIL. Constituição (1988). Constituição da República Federativa do Brasil de 1988. Diário Oficial da União, 5 out. 1988. Disponível em: 
<http://www.planalto.gov.br/ccivil_03/Constituicao/Constituicao.htm.>. Acesso em: 02 set. 2016.

BRASIL. Lei no. 8.078, de 11 de setembro de 1990. Dispõe sobre a proteção do consumidor e dá outras providências. Disponível em: <http://www.planalto.gov.br/ccivil_03/leis/L8078.htm.>. Acesso em: 08 set. 2016.

BRASIL. Lei no 6.404, de 15 de dezembro de 1976. Dispõe sobre as Sociedades por Ações. Diário Oficial da União, 15 dez. 1976. Disponível em: <http://www.planalto.gov.br/ccivil_03/leis/L6404compilada.htm.>. Acesso em: 02 set. 2016.

BRASIL. Lei no 10.406, de 10 de janeiro de 2002. Institui o Código Civil. Diário Oficial da União, 10 jan. 2002. Disponível em: <http://www.planalto.gov.br/ccivil_03/leis/2002/L10406.htm.>. Acesso em: 02 set. 2016.

COBRA, Marcos. Marketing Básico. São Paulo: Atlas, 1997.

CORDEIRO, Antônio Manuel da Rocha e Menezes. Da boa fé no Direito Civil. Coimbra: Livraria Almedina, 1997.

COUTO E SILVA, Clóvis. A Obrigação Como Processo. São Paulo: José Bushatsky, 1976.

GABRICH, Frederico de Andrade. Análise Estratégica do Direito. Belo Horizonte: Universidade Fumec, 2010.

GABRICH, Frederico de Andrade. Inovação no Direito. Belo Horizonte: Universidade Fumec, 2012.

GABRICH, Frederico de Andrade. O Princípio da Informação. Belo Horizonte: Fumec, 2010.

GALlO, Carmine. Faça como Steve Jobs - e realize apresentações incríveis em qualquer situação. São Paulo: LeYa, 2010.

GRACIOSO, Francisco. Propaganda: engorda e faz crescer a pequena empresa. São Paulo: Atlas, 2002.

GUIMARÃES, Paulo Jorge Scartezzini. A informação ao consumidor e a responsabilidade civil solidária. Revista de Direito do Consumidor, São Paulo, n. 38, p. 290-291, abr.-jun. 2001.

KOTLER, Philip. Administração de Marketing. São Paulo: Atlas, 2001.

MARTINS-COSTA, Judith. A Boa-Fé no Direito Privado. São Paulo: Revista dos Tribunais, 1999.

MORIN, Edgar. A religação dos saberes: o desafio do Século XXI. 2. ed. Rio de Janeiro: Bertrand do Brasil, 2002. 
MORIN, Edgar. Os sete saberes necessários à educação do futuro. São Paulo: Cortez, 2004

RIO GRANDE DO SUL. Tribunal de Justiça. Apelação Cível 70034535450. Relator: Lúcia de Fátima Cerveira. Diário da Justiça, 09 mai. 2011. Disponível em: <http://www.tjrs.jus.br/busca/?tb=proc> Acesso em: 05 set. 2016.

ROCHA, Cármen Lúcia Antunes. Princípios Constitucionais da Administração Pública. Belo Horizonte: Livraria Del Rey Editora, 1994.

SANTOS, Gilmar. Princípios da Publicidade. Belo Horizonte: Editora UFMG, 2005.

SÃO PAULO. Tribunal de Justiça. Apelação Cível 4014023-75.2013.8.26.0405. Relator: Mario de Oliveira. Diário Oficial do Estado, 12 jun. 2015. Disponível em: $<$ http://esaj.tjsp.jus.br/cpo/sg/search.do?conversationId=\&paginaConsulta=1\&localPesquisa.c $\mathrm{dLocal}=1 \& \mathrm{cbPesquisa}=$ NUMPROC\&tipoNuProcesso=UNIFICADO\&numeroDigitoAnoUnif icado $=4014023-75.2013 \&$ foroNumeroUnificado $=0405 \&$ dePesquisaNuUnificado $=4014023$ 75.2013.8.26.0405\&dePesquisaNuAntigo=>. Acesso em: 05 set. 2016.

SHIMP, Terence. Propaganda e promoção: aspectos complementares da comunicação integrada de marketing. Porto Alegre: Bookman, 2002. 